\title{
Gauging Housing Supply in Canada: A Stock Approach
}




\title{
WP/15/128
}

\section{IMF Working Paper}

\section{Gauging Housing Supply in Canada: A Stock Approach}

\author{
by Julien Reynaud
}

IMF Working Papers describe research in progress by the author(s) and are published to elicit comments and to encourage debate. The views expressed in IMF Working Papers are those of the author(s) and do not necessarily represent the views of the IMF, its Executive Board, or IMF management.
I N
N T E R D D
NATION A L
$M O N E T A R Y$
F U N D 
Western Hemisphere Department

\title{
Gauging Housing Supply in Canada: A Stock Approach \\ Prepared by Julien Reynaud ${ }^{1}$
}

Authorized for distribution by Trevor Alleyne

June 2015

IMF Working Papers describe research in progress by the author(s) and are published to elicit comments and to encourage debate. The views expressed in IMF Working Papers are those of the author(s) and do not necessarily represent the views of the IMF, its Executive Board, or IMF management.

\begin{abstract}
This paper estimates Canada's housing stock to gauge the supply-side component of the recent exuberance in the Canadian housing sector. The paper adds to the current related literature by focusing on housing units and reconstructing housing stock and households series. An error correction model is estimated at the provincial level over the period 1980-2013 to estimate a measure of housing stock desequilibrium. The model predicts an excess supply in the order of $1 / 2$ percent above the housing stock level consistent with fundamentals as of 2013.
\end{abstract}

JEL Classification Numbers: O18, R21, R31.

Keywords: Housing, Real Estate, Canada.

Author's E-Mail Address: jreynaud@imf.org

\footnotetext{
${ }^{1}$ I would like to thank David Albouy, Roberto Cardarelli, Jihad Dagher, Erik Drysdale, Richard Gabay, Paulo Medas, Christos Ntantamis, and Fotios Raptis for their comments and suggestions, as well as participants to the 47th Annual Conference of the Canadian Economics Association. Tim Mahedy provided excellent research assistance.
} 


\section{Content}

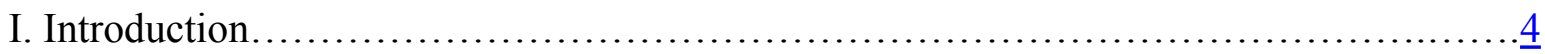

II. Reconstructing Canada's Housing Stock and Household Series....................... $\underline{5}$

A. Housing Stock Series.............................................. $\frac{5}{5}$

B. Household Formation.................................................. $\frac{8}{9}$

C. Vacancy Ratio........................................................ 9

III. Modeling Housing Unit's Supply ......................................... $\frac{10}{14}$

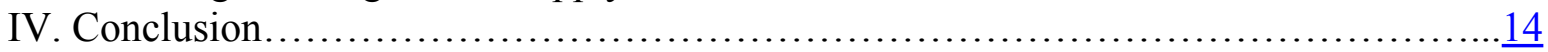

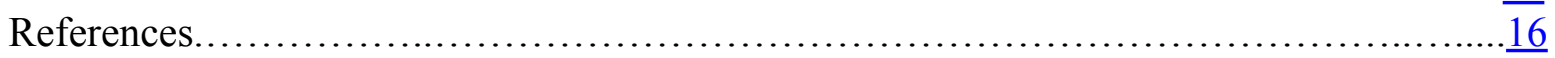

Appendix. Data Sources........................................................

\section{Figures}

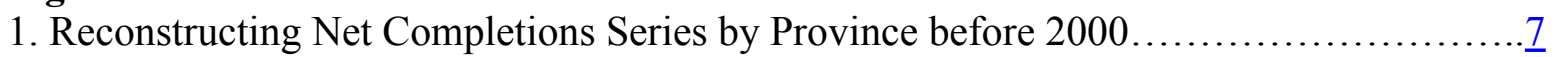

2. Computed Housing Stock by Province..........................................

3. Computed Households by Province............................................

4. Computed Excess Vacancy......................................................

5. Computed Vacant Units by Province...........................................

6. Estimated Housing Disequilibrium: Contribution by Province $\ldots \ldots \ldots \ldots \ldots \ldots \ldots \ldots \ldots \ldots \ldots \ldots$

\section{Tables}

1. Reconstructing the Housing Stock: Data Sources.................................

2. Estimation Results................................................... 


\section{INTRODUCTION}

Like in many other advanced economies, the Canadian housing sector experienced some exuberance over the last decade. Demand for housing has increased sharply, with real house prices almost doubled since early 2000s, the largest increase among advanced economies over the period according to the Organization for Economic Co-operation and Development (OECD, 2012). This increase has also been relatively broad based across the provinces. On the supply side, the last decade witnessed a boom in investment in new housing that helped push up home ownership rates to historical highs (Dupuis and Zheng, 2010). More recently, thanks to strong monetary and fiscal stimulus measures in the aftermath of the Great Recession, it took only a year and a half for Canadian residential investment to return to its pre-recession level, against the average 3 to 4 years in previous cycles (Bank of Canada, 2011). Yet, the last time residential investment-to-GDP ratio reached the 7 percent threshold, the Canadian housing sector went through a long subsequent period of stagnation. With current house prices and construction activity at historical highs, an adjustment is likely to take place in the coming years.

The bulk of research on the Canadian housing sector focuses on explaining the demand-side determinants. The wealth effect from the sharp increase in the terms of trade, a constant increase in labor force participation and strong net migration flows may have pushed up house prices. Demand for housing was also sustained by financial innovation and the steady decline in real mortgage rates also boosted demand as affordability of housing reached historical low levels. While the fundamentals behind housing demand have been extensively studied, only a few have looked at the supply side. Yet, according to the Bank of Canada (Dupuis and Zheng, 2010; Bank of Canada, 2013) and the Canadian Mortgage and Housing Corporation (Lewis, 2008), the completion of new housing units outpaced the demographic component of demand for housing units from 2002 to 2008, i.e. household formation, which inevitably raises concern about potential overbuilding and therefore excess supply.

This paper estimates Canada's housing stock to determine whether there is an excess supply of housing units. To do so, I proceed as follows: in the following section, I construct yearly time series of Canada's housing stock and household formation at the provincial level. In section three, I estimate an empirical model in the spirit Ball et al. (2010) to derive an estimate of the equilibrium housing stock where the housing stock is a function of a set of underlying fundamentals (including household formation, household disposable income, construction costs, mortgage rates, and house prices growth). The empirical model estimates an error-correction equation controlling for nonstationarity using pooled mean-group estimator for a panel of the ten provinces over the period 1982-2013. Disequilibrium in the housing stock is thus derived by comparing current housing units with the predicted values of the model. The results reveal some excess supply in housing units, particularly during in the build-up of the Great Recession, during which there were about 120,000 housing units in excess, or slightly above 1 percent of the total housing stock. 


\section{Reconstructing Canada’s Housing Stock And Household Series}

\section{A. Housing Stock}

There are some shortcomings in publicly-available data of housing indicators in Canada, particularly on the housing stock and household formation. Series published by Statistics Canada (StatCan) on the housing stock have been discontinued in 2000. Afterward, the main source of data on Canada housing stock is the CENSUS that provides household and private dwelling estimates every five years. The latter is also subject to biases, in particular the under-estimation of dwellings and households given the method of counting (i.e. missed household during the counting) (Gabay, 2011).

To reconstruct series of housing stock and household formation we use a simple stock model as follows (IMF, 2012). The stock of existing housing $\left(H_{t}\right)$ is the sum of occupied units $O_{t}$, or equivalently the number of households, and vacant units $V_{t}$ :

$$
H_{t}=O_{t}+V_{t}
$$

Occupancy in period $t$ is defined as the occupancy in period $t-1$ plus net household formation $\left(H F_{t}^{n}\right)$ :

$$
\begin{aligned}
& O_{t}=O_{t-1}+H F_{t}^{n} \\
& H F_{t}^{n}=I N_{t}-O U T_{t}
\end{aligned}
$$

where $I N_{t}$ is the number of newly occupied units, or gross household formation, and $O U T_{t}$ the newly vacated units. Vacant units in period $t$ are defined as the vacancy in period $t-1$ minus net household formation $\left(H F_{t}^{n}\right)$ and demolition $\left(D E M_{t}\right)$ plus newly built units $N E W_{t}$ and additions, $A D D_{t}$ :

$$
V_{t}=V_{t-1}-H F_{t}^{n}-D E M_{t}+N E W_{t}+A D D_{t}
$$

Excess supply is defined as:

$$
H_{t}-H_{t}^{*}=\left(O_{t}-O_{t}^{*}\right)+\left(V_{t}-V_{t}^{*}\right)
$$

where $\left(V_{t}-V_{t}^{*}\right)$ is the excess vacancy, i.e. the difference between the current level of vacant units and its normal or equilibrium level, a measure commonly used to gauge the potential for construction activity. $\left(O_{t}-O_{t}^{*}\right)$ is the excess occupancy that occurs when household formation is above equilibrium.

Overbuilding is defined as the difference between the net change in the stock and net household formation. As the addition of new housing units is feeding the vacant housing segment in the first place, overbuilding appears when $\left(N E W_{t}+A D D_{t}-D E M_{t}\right)>H F_{t}^{n}$. This translates into $V_{t}>V_{t-1}$, which should ultimately increase the housing stock above the level determined by household formation when $\left(O_{t}=O_{t}^{*}\right)$.

Before estimating $H^{*}$ empirically, we need to reconstruct $H_{t}$. Statistics Canada provides data on the total net stock owned and rented, total vacant dwellings for rent or for sale, and occupied stock owned and rented, at both national and provincial level, from 1971 to 2000 at the yearly frequency. As per the stock model developed above and in accordance with 
StatCan methodology, the housing stock in period $t$ is defined as the stock in period $t-1$, plus newly added units (completions) and additions, minus demolitions.2

Starting from the latest available data for the housing stock (2000), the stock is identified as follows:

$$
H_{t}^{e}=H_{t-1}+N E W_{t}+A D D_{t}-D E M_{t}
$$

where the $\left(N E W_{t}\right),\left(A D D_{t}\right)$, and $\left(D E M_{t}\right)$ are defined as follows:

Table 1: Reconstructing the Housing Stock: Data Sources

\begin{tabular}{|l|l|l|}
\hline \multicolumn{1}{|c|}{ Data } & \multicolumn{1}{|c|}{ Title } & \multicolumn{1}{c|}{ Source } \\
\hline Stock & $\begin{array}{l}\text { Housing stock, dwelling units by type of } \\
\text { dwelling and tenure, annual (units). }\end{array}$ & Statistics Canada: Table 030-0001. \\
\hline Completion & $\begin{array}{l}\text { Housing starts, under construction and } \\
\text { completions, all areas, annual (units) }\end{array}$ & $\begin{array}{l}\text { Table 027-0009 Canada Mortgage } \\
\text { and Housing Corporation. }\end{array}$ \\
\hline Conversion & $\begin{array}{l}\text { Building permits, residential values and } \\
\text { number of units, by type of dwelling, annual }\end{array}$ & Statistics Canada. Table 026-0001. \\
\hline Demolition & $\begin{array}{l}\text { Building permits, demolitions by region, } \\
\text { annual (units) }\end{array}$ & $\begin{array}{l}\text { Statistics Canada. Table 026-0012. } \\
\text { Note: Demolition data at the } \\
\text { provincial level has been obtained } \\
\text { from StatCan. }\end{array}$ \\
\hline
\end{tabular}

Testing backward our estimated housing stock using 1971 as a starting point yields good results (Figure 1). With the exception of British Columbia for which the difference in two years is meaningful, our estimated net completions are generally consistent with StatCan estimates. Differences between our estimates and StatCan data are to be attributed to updated figures on demolitions I obtained in April 2013. Other issues could be due to backward revisions in data published by CMHC on completions and by StatCan on conversions. Overall, an interesting feature is that the computed estimates are generally lower than StatCan series, which will led to a downward bias in our estimates of excess supply.

\footnotetext{
${ }^{2}$ Because of the lack of information on the timing of conversions, we assumed all conversions occur within one year. In reality, some of them can take more time depending on the size of the building. Our assumption, however, is unlikely to have a large impact on the housing stock and on our yearly estimates of overbuilding, as conversions represent a relative small share of the overall number of new housing units added per year.
} 
Figure 1: Reconstructing Net Completions Series by Province before 2000 (in units)
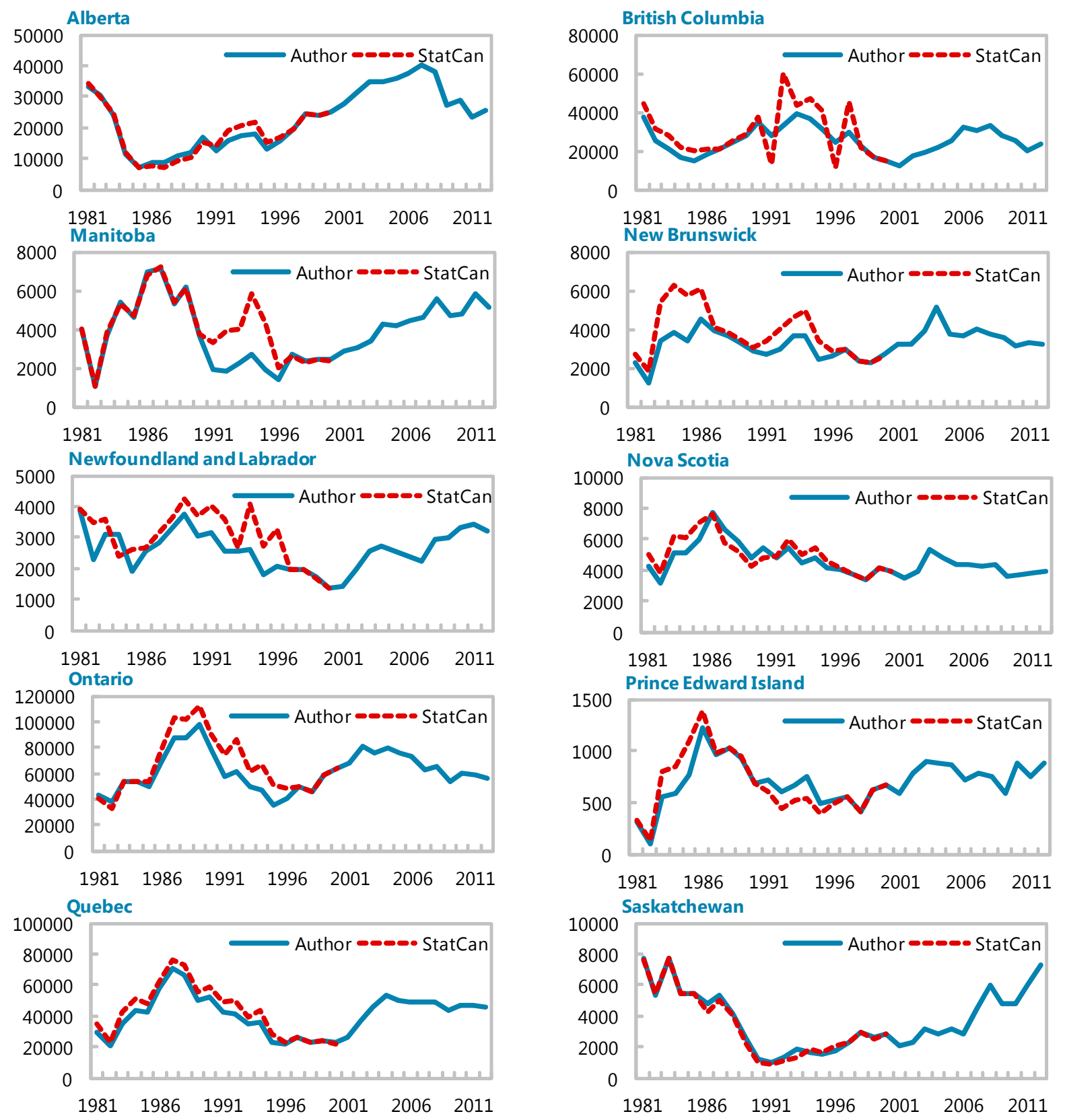

Source: CMHC, Statistics Canada, author's calculation

The results show that Canada's housing stock almost doubled over the last three decades, with Alberta and British Columbia posting the largest gains (Figure 2). Between 1980 and 2013, Canada's housing stock grew at a yearly average rate of 1.7 percent. The largest provinces posted the most dynamics trends, with Alberta and British Columbia growing at an average yearly 2 percent. This strong growth was at the expense of smaller provinces whose share in the total net stock diminished over the period. Ontario and Quebec shares of the national stock stagnated over this period, at around $1 / 3$ and $1 / 4$ respectively. 
Figure 2: Computed Housing Stock by Province

(in units)

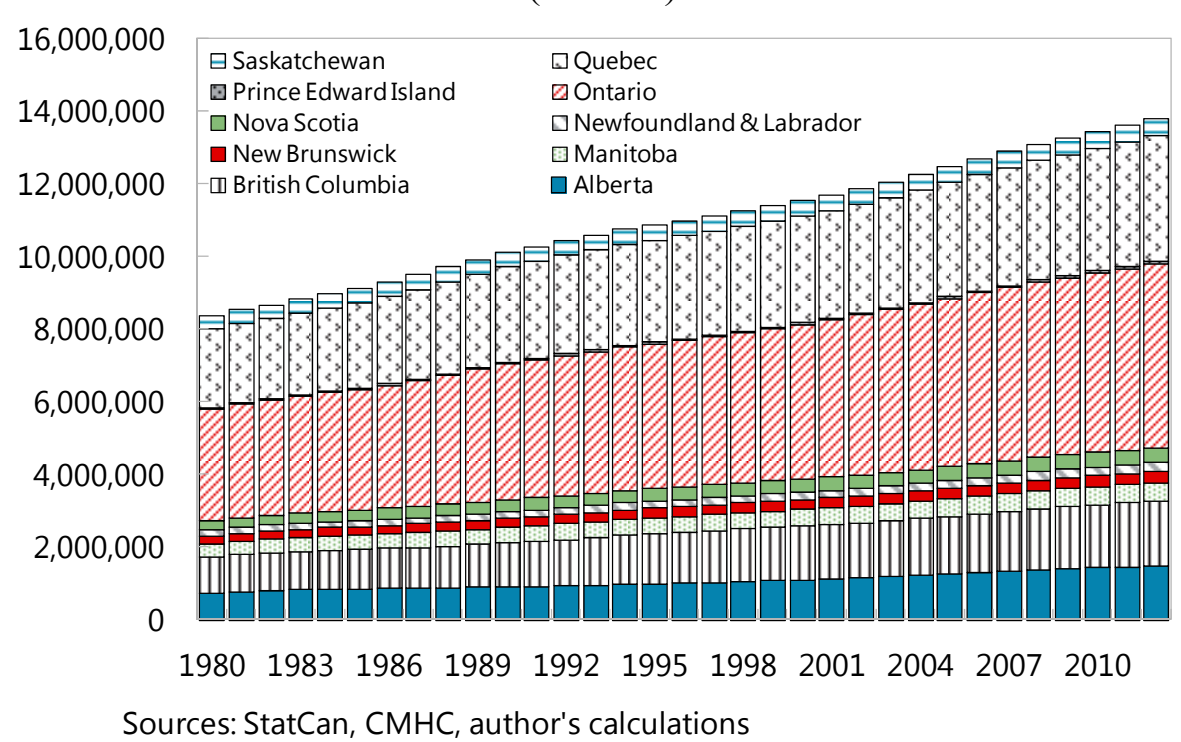

\section{B. Household Formation}

Ultimately, when assessing the supply of housing, one has to estimate the equilibrium of the number of households, household formation, and excess vacancy that is the result of overbuilding or exuberant construction. It is generally admitted that household formation is the result of the pace of population growth, the aging of the population, and preferences which are related to living arrangements (in particular the headship rate and the size of the household). The latter's influence could actually be subject to other factors such as rising real wages and increases in social benefits, and more generally financial conditions (CBO, 2008). The assumption that $\left(O_{t}=O_{t}^{*}\right)$ is therefore harder to sustain during boom or bust periods.

A recent reference on research focusing on Canada's household formation in the context of gauging overbuilding is Lewis (2008) that compared 5-years averages household formation from CENSUS to actual completion data. Lewis concluded that homebuilding activity tends to move in sync with changes in household formation. He found that construction activity was roughly in line with household formation up to 2001, and then from 2001 to 2006 the number of new homes constructed in Canada surpassed the net change in households by a considerable margin, pointing to overbuilding. Updating this analysis using the latest available CENSUS (2011) suggests that the cumulative supply of new housing units outpaced household formation by about 10 percent when comparing 2011 with 2001.

Using CMHC, StatCan and CENSUS data, I interpolated household formation to construct series for provinces at the annual frequency. Based on Gabay (2011), I use StatCan population data that provides as better count of population and therefore household, as compared to CENSUS who is biased downward due to counting issues, and extrapolate headship rate that represents the propensity of people in a given age group to form households. The headship rate is calculated as the number of primary household maintainers in that age group divided by the total number of people in the same age segment. The main challenge in estimating household formation lies in the non-demographic component, i.e. 
income growth and financial conditions as discussed above. Immigration both international and interprovincial is also an important factor in gauging household formation, in particular over the last two decades (Figure 3).

Figure 3: Computed Households by Province

(in units)

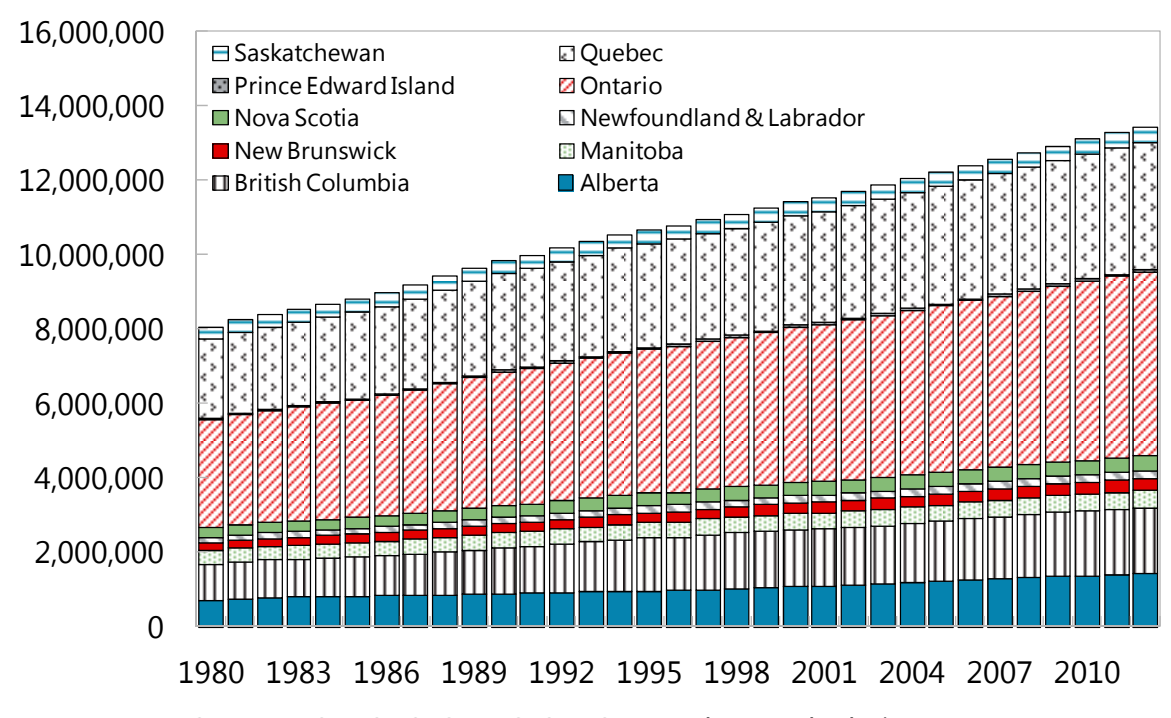

Sources: CENSUS, CMHC, StatCan, author's calculations

\section{Vacancy ratio}

With estimates available for both housing stock and household, we are able to deduce vacant housing units as per equation (1). The vacancy ratio, that is, the number of unoccupied units as a share of the housing stock, can therefore be calculated and is found to have reached historical highs in 2008. The lack of reliable data on second homes (whether they are occupied or not) makes it difficult to get an estimate of the "natural" number of unoccupied houses in Canada (i.e. the share of units that remain unoccupied due to frictions in the housing market when the latter is converging to equilibrium). Yet, assuming this share is relatively small and constant over time (in line with what can be deduced from the occasional Survey of Financial Security from Statistics Canada), as share of the total housing stock, the difference between the vacancy ratio and its historical average is a measure of the degree of disequilibrium in the housing stock. Doing so suggest an excess supply of housing of about $1 \frac{1}{2}$ percent of the total housing stock as of end 2013 (Figure 4). The provincial contributions are roughly in line with the respective stock sizes, yet the excess supply in Quebec appears relatively high (figure 5). While informative, these findings are based solely on demographics and thus fail to capture the influence of other determinants of construction activity. In the next section a model-based analysis of housing stock is developed, taking into account a few factors that are commonly believed to influence the supply and demand for housing. 
Figure 4: Computed Excess Vacancy

(vacant housing units to total housing units, percent deviation from sample average)

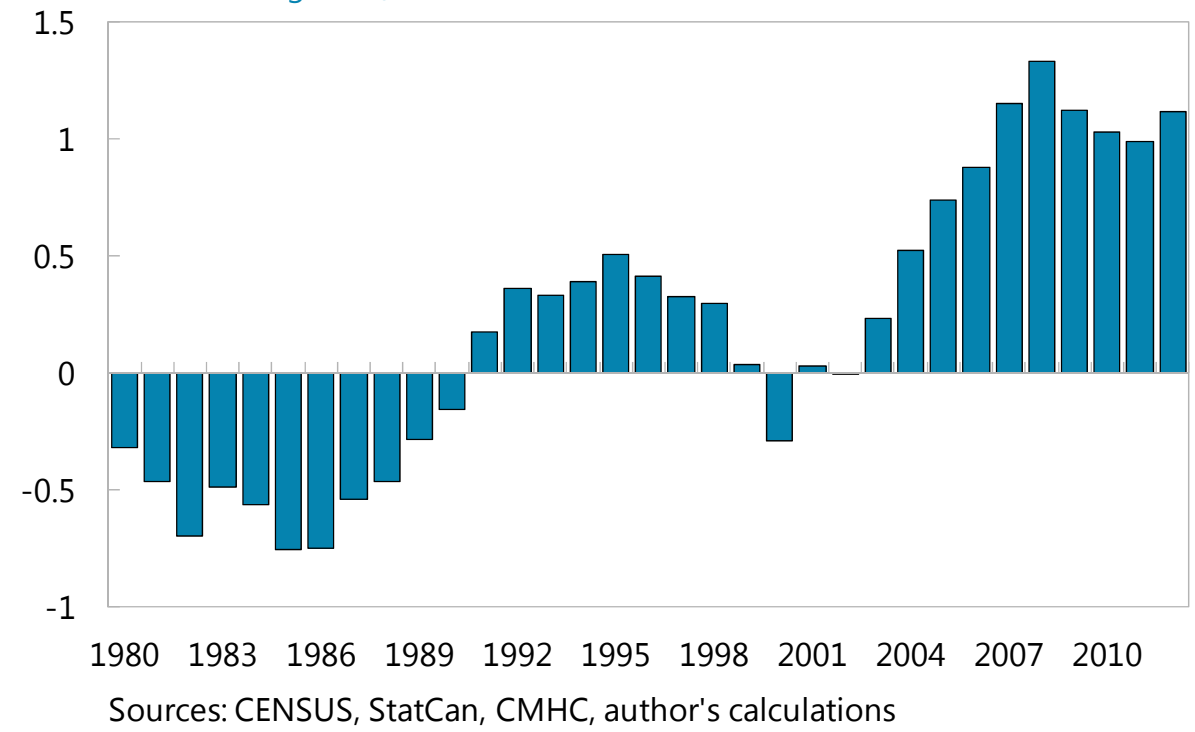

Figure 5: Computed Vacant Units by Province

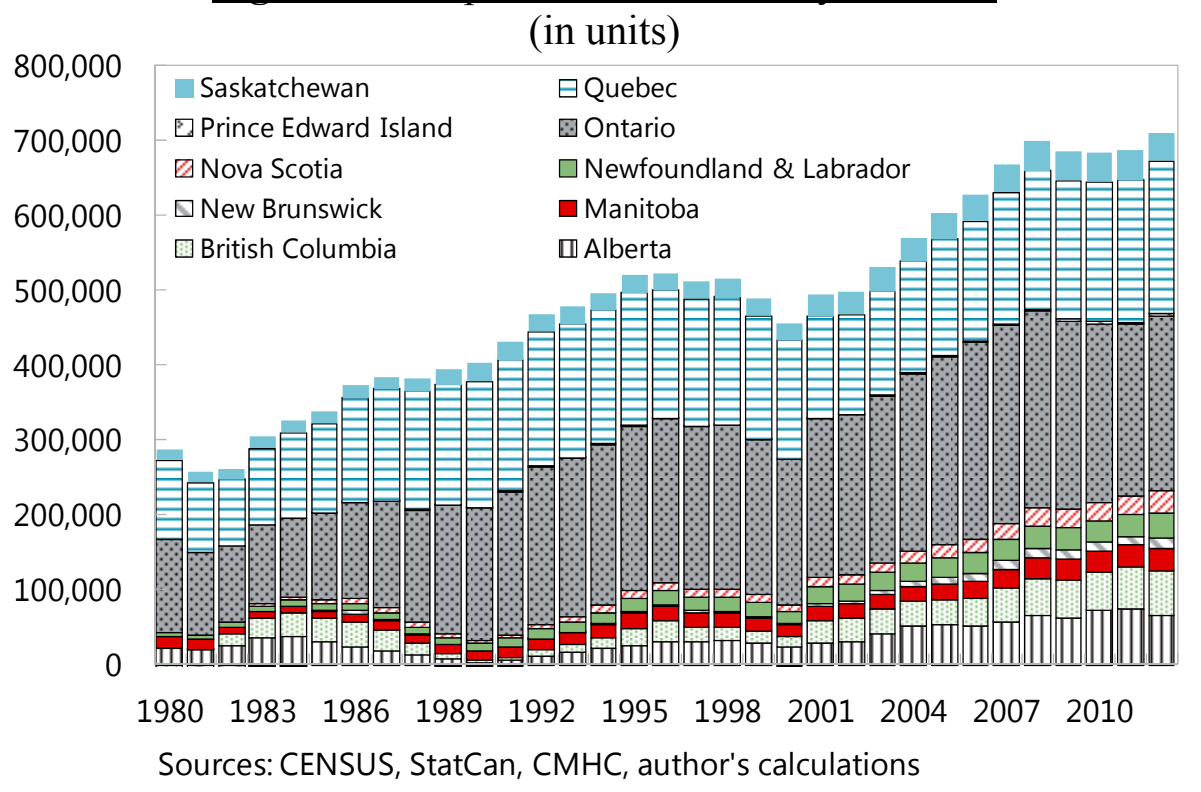

\section{Modeling Housing Units' SuPPly}

Most of the econometric models studying the housing sector in Canada have been produced by Bank of Canada researchers. Demers (2005) explains and forecasts real quarterly housing expenditures in Canada. Allen et al. (2006) model the long-run relationship of resale housing prices and found that new housing prices, union wage rates, and building permits explain resale housing price movements in the long run. Tomura (2008) looks at boom-bust housing 
cycle in the context of a dynamic stochastic general equilibrium model for a small open economy. Dupuis and Zheng (2010) is of interest for the purpose of my study as they estimate a system of equations that models Canadian housing investment (new and resale) and housing prices.

Mainly because of data constraints, there has been no study on the adequate level of the supply of housing units in Canada. Having resolved the data constraint issue in the previous section, a stock-adjustment model in the spirit of Ball et al. (2010) can be estimated to derive the equilibrium in housing stock $H^{*}$. From the simple static model in Section II.A, the stockadjustment equations follow:

$$
\begin{aligned}
& \dot{g}=\alpha_{1} g-\alpha_{2} R(H, O, Y) \\
& \dot{H}=\beta_{1} \dot{g}-\gamma H
\end{aligned}
$$

where (.) denotes a time derivative, $R$ the imputed rent, $Y$ real household disposable income, and $g$ real house prices. Equation (6) sets the arbitrage relationship for the housing market where the (unobservable) rent is a function of the housing stock, the occupied housing units or number of households, and real income; and $\left(\alpha_{1} g\right)$ is equal to the return on alternative assets with $\alpha_{1}=i-\pi+\delta$ with $i$ stands for the nominal market interest rate, $\pi$ for nonshelter CPI, and $\delta$ is the depreciation rate. In equation (7), the adjustment of the stock, or net completion, depends on real house prices growth and the size of the stock. Because $\left(\alpha_{1} g\right)$ is expected to represent the cost of the housing asset, i.e. taxation, expenditure and transaction cost, adding expected real capital gain (i.e. $\dot{g}^{e} / g$ ) to $\alpha_{1}$ will approximate the market efficiency condition. In the latter case one has to take into account a proxy of construction cost when estimating (7).

The estimated housing stock equilibrium can be derived from (6) and (7) as follows:

$$
\ln (H)=\rho_{1} \ln (g)+\rho_{2} \ln (O)+\rho_{3} \ln (Y)-\rho_{4} r+\varepsilon
$$

where $r=i-\pi+\delta-\left(\dot{g}^{e} / g\right)$.

From (8), the housing stock disequilibrium is therefore recovered using (5). To estimate $\mathrm{H}^{*}$ we estimate an error-correction specification controlling for nonstationarity using pooled mean-group estimator. This model constrains the long-run coefficient vector to be equal across panels while allowing for group-specific short-run and adjustment coefficients. Because the calculation of $\left(\dot{g}^{e} / g\right)$ is bound to data constraint, we estimate (8) with $r=i-$ $\pi$ and add a proxy for construction cost. The latter is proxied by the share of construction workers into workers of the good-producing industries. This measure evolves in line with the standard weekly average earnings of construction sector workers, which is predominantly used since wages represent the largest share of construction cost. The equilibrium in the good-producing labor market indeed sets wages, although one can argue that unions in the 
construction sector in Canada are powerful enough to limit wage flexibility. Housing stock and households are entering as logarithms, as well as household average after-tax income. House prices are based on average prices provided by the Canadian Real Estate Association and are deflated by CPI excluding shelter provincial indices. The model is estimated over 1982-2013 on yearly data for the ten Canadian provinces.

Under a dynamic panel specification, from (8), an autoregressive distributive lag $\left(p, q_{1}, \ldots, q_{p}\right)$ process as follows is assumed:

$$
h_{i, t}=\sum_{j=1}^{p} \sigma_{i, j} h_{i, t-j}+\sum_{j=0}^{q} \tau_{i, j} X_{i, t-j}+\mu_{i}+\epsilon_{i, t}
$$

where the number of provinces $i=1, \ldots, N$ with $N=10$; the number of periods $t=1, \ldots, T$ with $T=31 ; X_{i, t}$ is a $k \times 1$ vector of explanatory variables including households, household disposable income, mortgage rate, construction cost, and house prices growth, $; \tau_{i, t}$ are the $k$ $\mathrm{x} 1$ coefficient vectors; $\sigma_{i, t}$ are the scalars; and $\mu_{i}$ is the group-specific effect. Estimating an error-correction model leads to the following reparameterization of (9):

$$
\Delta h_{i, t}=\varphi_{i}\left(h_{i, t-1}-\omega_{i} X_{i, t}\right)+\sum_{j=1}^{p-1} \rho_{i, j}^{*} \Delta h_{i, t-1}+\sum_{j=0}^{q-1} \tau_{i, j}^{*} X_{i, t-j}+\mu_{i}+\epsilon_{i, t}
$$

where $\varphi_{i}=-\left(1-\sum_{j=1}^{p-1} \rho_{i, j}\right) ; \omega_{i}=\sum_{j=0}^{q-1} \tau_{i, j}^{*} /\left(1-\sum_{k} \rho_{i, k}\right) ; \rho_{i, j}^{*}=-\sum_{m=j+1}^{p-1} \rho_{i, m}$; and $\tau_{i, j}^{*}=-\sum_{m=j+1}^{q} \tau_{i, m}$

Table 2 presents the results. The main results are presented in the "Pooled mean-group" column. The upper panel of the table shows the long-run relation, i.e the normalized cointegration relationship. The demographic component is significant, positive and turns out to be the largest coefficient which is line with expectation that household demand is the main determinant of the housing stock. As expected as well, household income is also positive and significant. Interest rate plays negatively on the level of the housing stock, while construction cost is also negatively linked to the stock but not significant. Finally, the coefficient on house prices is negative and significant, suggesting that an increase in prices will lower the demand for housing stock as expected. The disequilibrium reflects the fact that the housing stock cannot adjust immediately to changes in demand, arising from variations in income, demographics or interest rates.

Turning now to the short-run adjustment, the speed of adjustment to the disequilibrium in housing stock is relatively high at around -0.2. This adjustment varies quite widely across provinces. Interestingly, the growth in lagged house prices has a positive impact on the changes in housing stock, in line with expectations that the profitability of residential investment is positively correlated with expectations of price increase. 
Table 2: Estimation Results of Equation (9)

\begin{tabular}{|c|c|c|c|c|c|c|c|c|c|c|c|c|}
\hline & $\begin{array}{c}\text { Pooled } \\
\text { mean-group }\end{array}$ & $\begin{array}{c}\text { Dynamic } \\
\text { fixed-effects }\end{array}$ & $\mathrm{AL}$ & $\mathrm{BC}$ & MN & NB & NL & NS & ON & PEI & QU & SK \\
\hline \multicolumn{13}{|l|}{ Long-run } \\
\hline Households & $\begin{array}{c}0.8783^{a} \\
0.0170\end{array}$ & $\begin{array}{c}0.9034^{a} \\
0.0265\end{array}$ & & & & & & & & & & \\
\hline Income & $\begin{array}{c}0.1297^{a} \\
0.0109\end{array}$ & $\begin{array}{c}0.1869^{a} \\
0.0227\end{array}$ & & & & & & & & & & \\
\hline Interest rate & $\begin{array}{c}-0.4339^{a} \\
0.0428\end{array}$ & $\begin{array}{c}-0.6609^{b} \\
0.0872\end{array}$ & & & & & & & & & & \\
\hline House prices & $-0.0211^{b}$ & $\begin{array}{c}-0.0797^{a} \\
0.0222\end{array}$ & & & & & & & & & & \\
\hline Construction cost & $\begin{array}{c}0.0072 \\
0.0058\end{array}$ & $\begin{array}{c}-0.0138 \\
0.0139\end{array}$ & & & & & & & & & & \\
\hline \multicolumn{13}{|l|}{ Short-run } \\
\hline Error-correction & $\begin{array}{c}-0.2041^{a} \\
0.0406\end{array}$ & $\begin{array}{c}-0.1246^{a} \\
0.0155\end{array}$ & $\begin{array}{c}-0.5365^{a} \\
0.1160\end{array}$ & $\begin{array}{c}-0.2343^{a} \\
0.0592\end{array}$ & $\begin{array}{c}-0.2073^{a} \\
0.0253\end{array}$ & $\begin{array}{c}-0.1299^{b} \\
0.0598\end{array}$ & $\begin{array}{c}-0.1209^{a} \\
0.0277\end{array}$ & $\begin{array}{c}-0.1778^{a} \\
0.0248\end{array}$ & $\begin{array}{c}-0.0676^{a} \\
0.0226\end{array}$ & $\begin{array}{c}-0.2219^{a} \\
0.0508\end{array}$ & $\begin{array}{c}-0.2089^{a} \\
0.0255\end{array}$ & $\begin{array}{l}-0.1354^{a} \\
0.0178\end{array}$ \\
\hline Households & $\begin{array}{l}0.1508^{a} \\
0.0583\end{array}$ & $\begin{array}{l}0.2127^{a} \\
0.0353\end{array}$ & $\begin{array}{c}0.0680 \\
0.1869\end{array}$ & $\begin{array}{c}0.1206 \\
0.0834\end{array}$ & $\begin{array}{l}0.2717^{a} \\
0.0863\end{array}$ & $\begin{array}{c}0.1320 \\
0.1239\end{array}$ & $\begin{array}{l}0.0879^{c} \\
0.0549\end{array}$ & $\begin{array}{r}-0.0021 \\
0.0852\end{array}$ & $0_{0.5486}^{a}{ }^{a}$ & $\begin{array}{r}-0.1363 \\
0.1595\end{array}$ & $0.2744^{a}$ & $\begin{array}{l}0.1430^{a} \\
0.0500\end{array}$ \\
\hline Income & $\mathrm{c}^{0.0082^{b}}{ }^{b}$ & $\begin{array}{l}0.0077^{c} \\
0.0043\end{array}$ & $\begin{array}{c}0.0226 \\
0.0196\end{array}$ & $\begin{array}{r}-0.0011 \\
0.0197\end{array}$ & $\begin{array}{c}0.0118 \\
0.0090\end{array}$ & $\begin{array}{l}0.03011^{c} \\
0.0167\end{array}$ & $\begin{array}{r}-0.0078 \\
0.0062\end{array}$ & $\begin{array}{c}-0.0002 \\
0.0111\end{array}$ & $\begin{array}{c}0.0009 \\
0.0102\end{array}$ & $\begin{array}{c}0.0234 \\
0.0178\end{array}$ & $\begin{array}{c}0.0021 \\
0.0093\end{array}$ & $\begin{array}{r}-0.0002 \\
0.0056\end{array}$ \\
\hline Interest rate & $\begin{array}{c}-0.0164^{b} \\
0.0131\end{array}$ & $\begin{array}{c}0.0095 \\
0.0088\end{array}$ & $\begin{array}{c}0.0784 \\
0.0480\end{array}$ & $\begin{array}{c}0.0030 \\
0.0287\end{array}$ & $\begin{array}{r}-0.0110 \\
0.0144\end{array}$ & $\begin{array}{c}0.0039 \\
0.0189\end{array}$ & $\begin{array}{r}-0.0051 \\
0.0185\end{array}$ & $\begin{array}{c}0.0176 \\
0.0155\end{array}$ & $\begin{array}{c}-0.0181^{c} \\
0.0108\end{array}$ & $\begin{array}{l}0.0916^{b} \\
0.0350\end{array}$ & $\begin{array}{c}-0.0386^{a} \\
0.0122\end{array}$ & $\begin{array}{l}-0.0354^{a} \\
0.0123\end{array}$ \\
\hline House prices & $\begin{array}{c}0.0280^{a} \\
0.0070\end{array}$ & $\begin{array}{c}0.0420^{a} \\
0.0069\end{array}$ & $\begin{array}{r}-0.0035 \\
0.0193\end{array}$ & $\begin{array}{l}0.0533^{a} \\
0.0189\end{array}$ & $\begin{array}{c}0.0543^{a} \\
0.0148\end{array}$ & $\begin{array}{c}0.0339 \\
0.0263\end{array}$ & $\begin{array}{c}0.0420 \\
0.0182\end{array}$ & $\begin{array}{r}-0.0080 \\
0.0176\end{array}$ & $\begin{array}{c}0.0656^{a} \\
0.0193\end{array}$ & $\begin{array}{r}-0.0021 \\
0.0354\end{array}$ & $\begin{array}{c}0.0211 \\
0.0151\end{array}$ & $\begin{array}{l}0.0235^{a} \\
0.0083\end{array}$ \\
\hline Construction cost & $-0.0053^{c}$ & $\begin{array}{r}-0.0004 \\
0.0029\end{array}$ & $\begin{array}{r}-0.0048 \\
0.0151\end{array}$ & $\begin{array}{c}-0.0192^{b} \\
0.0087\end{array}$ & $\begin{array}{r}-0.0041 \\
0.0039\end{array}$ & $\begin{array}{c}-0.0179^{b} \\
0.0088\end{array}$ & $\begin{array}{r}-0.0006 \\
0.0043\end{array}$ & $\begin{array}{r}-0.0080 \\
0.0060\end{array}$ & $\begin{array}{r}0.0005 \\
0.0087\end{array}$ & $\begin{array}{r}0.0091 \\
0.0097\end{array}$ & $\begin{array}{r}0.0004 \\
0.0046\end{array}$ & $\begin{array}{c}-0.0085^{c} \\
0.0052\end{array}$ \\
\hline Constant & $\begin{array}{c}0.0840 \\
0.0194\end{array}$ & $\begin{array}{r}-0.0473 \\
0.0507\end{array}$ & $\begin{array}{c}0.2387^{c} \\
0.1447\end{array}$ & $\begin{array}{l}0.1107^{c} \\
0.0649\end{array}$ & $\begin{array}{c}0.0772^{c} \\
0.0473\end{array}$ & $\begin{array}{c}0.0403 \\
0.0325\end{array}$ & $\begin{array}{c}0.0452^{c} \\
0.0273\end{array}$ & $\begin{array}{c}0.0656^{c} \\
0.0408\end{array}$ & $\begin{array}{c}0.0434^{c} \\
0.0228\end{array}$ & $\begin{array}{c}0.0382 \\
0.0436\end{array}$ & $\begin{array}{c}0.1196^{b} \\
0.0559\end{array}$ & $\begin{array}{l}0.0610^{c} \\
0.0325\end{array}$ \\
\hline
\end{tabular}


From the estimations results, an estimate of the equilibrium housing stock $H^{*}$ can be compared to the current stock $H$ to derive the measure of disequilibrium. Figure 6 plots the overall housing disequilibrium in units by provinces. Not surprisingly, in view of the province's size, Ontario is the main contributor over the sample. The estimate captures well the early 1990s housing boom, as well as the one that occurred in the late 2000s. At its peak, the disequilibrium represented about 120,000 units, which translate into about 1 of the housing stock. ${ }^{3}$ Interestingly, the estimated disequilibrium turns out to be a good and robust predictor of house prices. However, since disequilibrium is not permanent, the measure of disequilibrium is expected to be stationary, possibly around zero so that market forces are bringing demand and supply to equalize over time.

Figure 6: Estimated Housing Disequilibrium: Contribution by Province (in units)

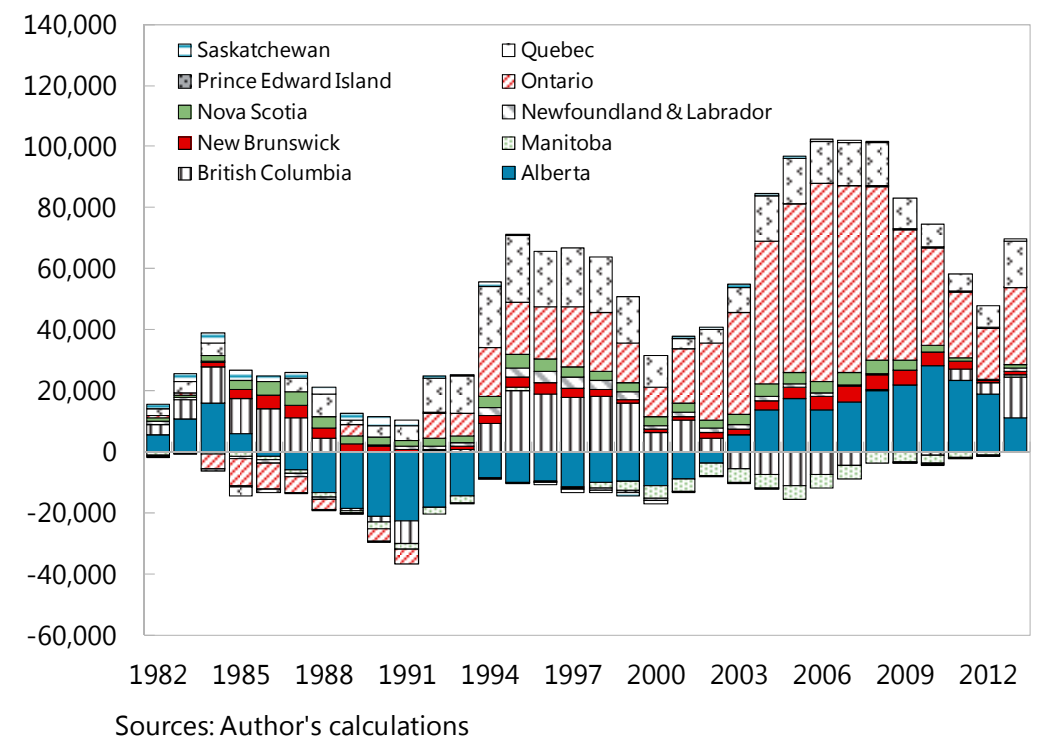

\section{CONCLuSion}

This paper intends to shed new light on the supply of housing units in Canada. It contributes to the existing literature by (i) providing yearly estimates of housing stock and household formation for the 10 Canadian provinces over the period 1980-2013, (ii) and by estimating excess supply in housing units for the ten Canadian provinces. The empirical results suggest that the Canadian housing market was in excess supply by about 0.5 percent of the total housing stock by end 2013. In comparison, at the highs of the 2009 Great Recession the

\footnotetext{
${ }^{3}$ As discussed in section II, because the estimates of housing stock are slightly inferior to the one of StatCan, the results are biased downwards. The estimates presented are therefore to be taken as the lower bounds of disequilibrium. Indeed, running the same model on StatCan series prior 2000 led to an excess supply closer to $1 \frac{1}{2}$ of total supply. In a previous study (IMF, 2013) in which I focused on construction rather than net completions and for which I used StatCan data, excess supply was found to be slightly larger over the sample period.
} 
excess supply was found to have reached almost 1 percent, and in the aftermath of the early1990s housing crisis, the excess supply reached about 0.6 percent of the total stock and house prices went through a decade long stagnation. 


\section{REFERENCES}

Allen, Jason , Robert Amano, David Byrne and Allan Gregory, 2006. "Canadian City Housing Prices and Urban Market Segmentation”.

Ball, Michael, Geoffrey Meen and Christian Nygaard, 2010. "Housing supply price elasticities revisited: Evidence from international, national, local and company data". Journal of Housing Economics 19, pp. 255-268.

Bank of Canada, 2011. "Housing in Canada". Remarks by Mark Carney, Governor of the Bank of Canada, Vancouver Board of Trade, 15 June 2011

Bank of Canada, 2013. Monetary Policy Report, April 2013.

Congressional Budget Office, 2008. "The Outlook for Housing Starts, 2009 to 2012”, Background Paper, Pub. No. 3183.

Demers, Frederick, 2005. "Modelling and Forecasting Housing Investment: The Case of Canada". Bank of Canada, Working Paper No. 2005-41.

Dupuis, David, and Yi Zheng, 2010. "A Model of Housing Stock for Canada". Bank of Canada, Working Paper No. 2010-19.

Egebo, Thomas, Pete Richardson and Ian Lienert, 1990. "A model of housing investment for the major OECD economies”. OECD, Economic Studies No. 14 (Spring 1990).

Gabay, Richard, 2011. "Long-term household projections-2011 update”. Canadian Mortgage and Housing Corporation, Socio-economic Series 11-008.

International Monetary Fund, 2012. United States Selected Issues, IMF Country Report No. $12 / 214$.

International Monetary Fund, 2013. Canada Selected Issues, IMF Country Report No. 13/41.

Lewis, Roger, 2008. "2006 Census Housing Series: Issue 1-Demographics and Housing Construction”. Canadian Mortgage and Housing Corporation, Socio-economic Series 08-004.

Organization for Economic Co-operation and Development, 2012. OECD Economic Outlook No. 92 (database).

Tomura, Hajime, 2008. "A Model of Housing Boom and Bust in a Small Open Economy”. Bank of Canada, Working Paper 2008-9. 


\section{APPEndix. DAta Sources}

Sources of the data used for the regression model:

\begin{tabular}{|l|l|}
\hline \multicolumn{1}{|c|}{ Variable } & \multicolumn{1}{|c|}{ Source } \\
\hline Housing stock & $\begin{array}{l}\text { StatCan and author's calculations (as describe } \\
\text { above) }\end{array}$ \\
\hline Household formation & $\begin{array}{l}\text { CENSUS, StatCan and author's calculations (as } \\
\text { describe above) }\end{array}$ \\
\hline $\begin{array}{l}\text { Real household average } \\
\text { after-tax income }\end{array}$ & Haver \\
\hline Construction cost & Haver \\
\hline Mortgage rate & Haver \\
\hline CPI excluding shelter & Haver \\
\hline House prices & $\begin{array}{l}\text { CREA (average house prices) and shelter CPI for } \\
\text { MN, NB, NL, NS, PEI and SK from 1980 to 1986. }\end{array}$ \\
\hline
\end{tabular}

